\title{
Effect of Salt Stress on Growth, Antioxidant Enzymes, Lipid Peroxidation and Some Metabolic Activities in Some Fresh Water and Marine Algae
}

\author{
A. M. Farghl, ${ }^{2 *}$, M.A.K. Shaddad, H.R. Galal, ${ }^{2}$ and E. A. Hassan, ${ }^{2}$ \\ ${ }^{1}$ Department of Botany, Faculty of Science, Assiut University, Assiut \\ and ${ }^{2}$ Department of Botany, Faculty of Science, South Valley \\ University, Qena.
}

\begin{abstract}
7 HE OBJECTIVE of this research was to compare physiological response of fresh water algae (Chlorella vulgaris) and marine algae (Chlorella salina) to different salinity levels. These algae were isolated and cultivated in appropriate media for a period of 8 days. C. vulgaris could survive till 0.8 molar $\mathrm{NaCl}$, while the marine strain (C. salina) survived up to 2 molar $\mathrm{NaCl}$. Thus, the marine alga showed a wide range of salinity tolerance, whereas the fresh water alga showed a narrows range of salinity tolerance. The dry weight of $C$. salina was 2 -folds at $1 \mathrm{M} \mathrm{NaCl}$ and slightly changed at $2 \mathrm{M} \mathrm{NaCl}$ as compared to the control value. In $C$. vulgaris dry weight was progressively decreased with increase of salinity. Hypo and hyper saline media induced significant stimulation in photosynthesis pigments, carbohydrate, protein, $\mathrm{Na}^{+}$and $\mathrm{K}^{+}$contents in $C$. salina. On the other hand, free amino acids, proline, MDA contents and antioxidant enzyme activities (SOD, CAT, POD and APX) were generally decreased. In contrary, salt stress exerted inhibitory effects on photosynthetic pigments, carbohydrate, protein and $\mathrm{K}^{+}$contents of the fresh water alga. Free amino acids, proline, $\mathrm{Na}^{+}$, MDA contents and antioxidant enzyme activities were markedly increased in $C$. vulgaris with increase of salinity stress. The great salinity tolerance of $C$. salina, compared to $C$. vulgaris may be due to the effect of habitat on the behavior of the algae as being controlled with specific habitat gene (s).
\end{abstract}

Keywords: Fresh water algae; Marine algae; Chlorella; Salt stress, Physiological responses.

Abbreviation: Chlorophyll a (chl.a), chlorophyll b (chl.b), carotenoid (cart.), superoxide dismutase (SOD), catalase (CAT), peroxidase (POD), ascorbate peroxidase (APX), malondialdehyde (MDA), sodium chloride( $\mathrm{NaCl})$, thiobarbituric acid (TBA), trichloroacetic acid (TCA), reactive oxygen species (ROS).

Algae are inhabitants of biotopes characterized by varying salinities, and as a result they have attracted considerable attention in salt tolerance studies. They have served as model organisms for better understanding of salt acclimation to more complex physiological processes of higher plants (Alkayal et al., 2011).

*Corresponding author's e-mail: farghla@yahoo.com 
Algae differ in their adaptability to salinity and based on their tolerance extent they are grouped as halophilic (salt requiring for optimum growth) and halo tolerant (having response mechanism that permits their existence in saline medium). In either case, algae produce some metabolites to protect from salt injury and to balance with the surrounding osmotic (Rao et al., 2007).

Salinity stress affects algae and plants through osmotic and ionic stresses. Water deficit brings about osmotic stress while excess $\mathrm{Na}^{+}$and $\mathrm{Cl}^{-}$and reduction in the uptake of other mineral nutrients can bring about ionic imbalances or stress (Ashraf \& Harris, 2004 and Mgbeze \& Omodamwen, 2011).

Nitrogen containing compounds such as amino acids, amides, protein, and quaternary ammonium compounds have been found helpful in osmoregulation (Grumet et al., 1985) and in tolerance of ion toxicity under salt stress (Turhan et al., 2008). The way these compounds are accumulated differs between species and ranges from only one to several different compounds being accumulated (Teixeira and Pereira, 2007).

The production of osmoprotectants or compatible solutes lowers the internal water potential of the cell, thus enabling the cell to take up water from the environment. Compatible solutes include mannitol and proline. Proline is produced in the cell from glutamate and its synthesis requires ATP and NADPH. Trying to maintain proper osmotic conditions may therefore be at a high energy cost which may be manifested as reduced growth rates and decrease in photosynthetic electron transport activities (Ashraf \& Harris, 2004 and Annan, 2014).

High salinity is known to cause both hyperionic and hyperosmotic effects in plants, leading to membrane disorganization, metabolic toxicity and increases in reactive oxygen species (ROS) (Jaleel et al., 2007a). The production of reactive oxygen species (ROS) such as singlet oxygen $\left({ }^{1} \mathrm{O}_{2}\right)$, superoxide radical $\left(\mathrm{O}_{2}{ }^{-}\right)$, hydroxyl radical $\left(\mathrm{HO}^{\prime}\right)$, and hydrogen peroxide $\left(\mathrm{H}_{2} \mathrm{O}_{2}\right)$ can be enhanced by stress and if the accumulation of ROS exceeds the capacity of plants to remove them, it will lead to oxidative stress (Kreslavski et al., 2007). As a result, photosystems could be damaged because of DNA mutation, protein denaturation, lipid peroxidation and chlorophyll bleaching as well as the loss of membrane integrity (Leshem et al., 2007).

Plants possess a number of various antioxidative enzymes that are involved in the detoxification of ROS and the avoidance of damage under salt stress (Sekmen et al., 2007). Plants with high levels of constitutive or induced antioxidants have been reported to have greater resistance to oxidative damage (Fuchen and Fang, 2007). ROS cause lipid peroxidation and production of highly toxic lipid derivatives, which in turn can modify cell functions and even may lead to cell death (Marnett, 2000).

Egypt. J. Bot., 55, No. 1 (2015) 
Malondialdehyde (MDA) content has been considered an indicator of oxidative damage. Thus, cell membrane stability has widely been utilized to differentiate salt-tolerant and salt-sensitive cultivars (Azevedo Neto et al., 2006).

Thus, the aim of the present study was to investigate the response to salt stress with emphasis on physiological and biochemical processes. This has been fried through comparing the adaptability of the two species Chlorella vulgaris (freshwater alga) and Chlorella salina (marine alga) to varied range of hypo and hyper saline environments and investigating their effects on growth (dry weight) and photosynthetic pigments. Attempts to elucidate whether antioxidant resistance mechanism is a strategy for these chlorophytes algae to counteract salinity changes were made by the determination of the levels of lipid peroxidation.

\begin{abstract}
Material and Methods
Algae and growth conditions

Chlorella vulgaris (unicellular, green fresh microalga) was isolated from sewage water of El-Salhya sewage station, Qena, Egypt and Chlorella salina (unicellular, green marine microalga) was isolated from Lake Marriott, Alexandria, Egypt. Chlorella vulgaris was grown in Bold's basal medium (Bischoff and Bold, 1963) with 0.4\& 0.8, M NaCl. MH medium (Guillard and Ryther, 1963) was used for growing of marine alga with variable $\mathrm{NaCl}$ concentrations $(0.4,0.8,1.0 \& 2.0 \mathrm{M} \mathrm{NaCl})$. The experiments were carried out in $250 \mathrm{ml}$ Erlenmeyer flasks. The cultures were incubated for 8 days at $25 \pm 1{ }^{\circ} \mathrm{C}$ and illumination was in $14 \mathrm{~h} \mathrm{light} / 10 \mathrm{~h}$ dark cycle, The algal cultures were supplied with dry air (Lorenzen, 1964) to provide $\mathrm{CO}_{2}$ necessary for photosynthesis, to prevent the settling of the cells at the bottom of the containers.
\end{abstract}

Measurement of growth and pigment content

$100 \mathrm{ml}$ of algal suspension were filtered through weighed glass fiber filter (sartorious GmbH Gottingen FRG). The cells after being precipitated on the filter paper were washed twice with distilled water and dried overnight in an oven at 105 $C^{\circ}$ to evaluate dry weight (Leganes et al., 1987). The contents of Chlorophyll a , Chlorophyll $\mathrm{b}$ and carotenoids were measured spectrophotometrically as described by Metzner et al. (1965).

\title{
Analytical methods
}

Soluble and total carbohydrates were determined by the anthrone sulphuric acid method as described by Badour (1959). Protein fractions (soluble and total) were determined according to Lowery et al. (1951). Free amino acids were extracted and determined according to Moore and Stein (1948). Proline content was determined according to Bates et al. (1973). Atomic absorption (Spectra Varian 55) was employed for sodium and potassium determination. 


\section{Estimation of lipid peroxidation}

Lipid peroxidation was measured as the amount of malondialdehyde (MDA) determined by thiobarbituric acid reactive substance (TBARS) as described by Heath and Packer (1968), using 0.5\% (w/v) thiobarbituric acid (TBA) in 20\% $(\mathrm{w} / \mathrm{v})$ trichloroacetic acid (TCA). The absorbance was measured at 532 and 600 $\mathrm{nm}$ by using extinction coefficient of $155 \mathrm{mM}^{-1} \mathrm{~cm}^{-1}$.

\section{Estimation of some antioxidant enzymes activity}

Enzyme extract was prepared as described by Mukherjee and Choudhuri (1983). Superoxide dismutase (SOD) (EC 1.15.1.1) activity was measured according to the method of Dhindsa and Matowe (1981). Catalase (CAT) (EC 1.11.1.6) activity was assayed according to Havir and Mellate (1987). Peroxidase (POD) (EC 1.11.1.7) activity was determined according to Klapheck et al. (1990). Ascorbate peroxidase (APX) (EC 1.11.1.11) activity was determined as the decrease in absorbance at $290 \mathrm{~nm}$ due to oxidized ascorbic acid (Asada and Chen, 1992).

\section{Statistical Analysis}

Each treatment was analyzed with at least three replicates, and standard deviation $( \pm$ S.D.) was calculated. Statistical analysis was done using the least significant difference test (L.S.D.) using the SPSS program (SPSS Chicago, IL, USA).

\section{Results and Discussion}

Response of growth and photosynthetic pigments to salt stress

Chlorella vulgaris (freshwater alga) and Chlorella salina (marine alga) differed in their ability to grow at different $\mathrm{NaCl}$ concentrations. The two species showed a remarkable tolerance to hypo and hyper saline conditions and survived in differently tested saline media. It was noticed that the growth (dry weight) of $C$. salina was enhanced progressively by increasing the salt level up to 1 molar $\mathrm{NaCl}$, where it reached 2-fold of the control value and was approximately comparable to the control at $2 \mathrm{M} \mathrm{NaCl}$ (Table1). On the other hand, the growth (dry weight) of $C$. vulgaris showed highly significant decrease by $84 \%$ at 0.8 molar $\mathrm{NaCl}$ as compared to the control (El-Sheekh and Omar, 2002). Ben-Amotz et al. (1985) reported that growth of Dunaliella salina in sea water augmented with different $\mathrm{NaCl}$ concentrations reaching a maximum growth rate and yield at $0.6 \mathrm{M} \mathrm{NaC} 1$. A significant inhibitory effect of $\mathrm{NaCl}$ on algal growth was observed above 2 molar.

Hypo and hyper salinity caused a significant stimulation in the concentrations of Chlorophylls a \& b and carotenoids. This stimulation was most obvious at $0.8 \mathrm{M} \mathrm{NaCl}$ (about 2-fold of the control). In C. vulgaris, salinity caused a marked and progressive inhibition in the content of the photosynthetic pigment contents. At 0.8 molar $\mathrm{NaCl}$, Chl.a, Chl.b and Carot. contents were reduced by about 65,53 and $83 \%$, respectively (Table 1 ). Consequently, Chl.a/b ratio decreased considerably by salt stress which may indicate that Chl.a is more sensitive to salt stress than Chl. b and carotenoid (Fathi and Asem, 2013). According to Hiremath Egypt. J. Bot., 55, No. 1 (2015) 
and Mathad (2010), reduced chlorophyll contents at higher salinities are due to decrease in photosynthetic rate because of salt osmotic and toxic ionic stress.

TABLE 1. Comparison between dry weight (DW) and photosynthetic pigments content (Chl.a, Chl.b \&Cart.) of C. vulgaris and C. salina grown under salt stress. Each value is a mean of replications \pm SD standard deviation.

\begin{tabular}{|c|c|c|c|c|c|c|}
\hline Strains & $\begin{array}{c}\text { Salinity } \\
\text { (M) }\end{array}$ & $\mathbf{D W}^{\#}$ & Chl. $a^{\#}$ & Chl. $b^{\#}$ & Cart. $^{\#}$ & Chl. $a / b$ \\
\hline \multirow{3}{*}{ C. vulgaris } & 0 & $0.62^{\mathrm{a}}{ }_{ \pm 0.21}$ & $0.26^{\mathrm{b}}{ }_{ \pm 0.05}$ & $0.15^{\mathrm{a}}{ }_{ \pm 0.05}$ & $0.06^{\mathrm{a}}{ }_{ \pm .03}$ & $1.73^{\mathrm{a}}{ }_{ \pm 0.81}$ \\
\hline & 0.4 & $0.38^{\mathrm{b}}{ }_{ \pm 0.07}$ & $0.13_{ \pm 0.04}^{\mathrm{a}}$ & $0.11^{\mathrm{ab}}{ }_{ \pm 0.04}$ & $0.03^{\mathrm{b}}{ }_{ \pm 0.02}$ & $1.18_{ \pm 0.83}^{\mathrm{b}}$ \\
\hline & 0.8 & $0.10^{\mathrm{bc}}{ }_{ \pm 0.02}$ & $0.09_{ \pm 0.02}$ & $0.07^{\mathrm{b}}{ }_{ \pm 0.01}$ & $0.01_{ \pm .01}^{\mathrm{bc}}$ & $1.28^{\mathrm{b}}{ }_{ \pm 0.56}$ \\
\hline \multirow{5}{*}{ C. salina } & 0 & $0.79^{\mathrm{a}}{ }_{ \pm 0.25}$ & $0.16^{\mathrm{a}}{ }_{ \pm 0.06}$ & $0.21^{\mathrm{a}}{ }_{ \pm 0.08}$ & $0.09^{\mathrm{a}}{ }_{ \pm 0.05}$ & $0.76^{\mathrm{ab}}{ }_{ \pm 0.28}$ \\
\hline & 0.4 & $0.99^{\mathrm{a}}{ }_{ \pm 0.12}$ & $0.21^{\mathrm{ab}}{ }_{ \pm 0.04}$ & $0.29^{\mathrm{ab}}{ }_{ \pm 0.10}$ & $0.11^{\mathrm{a}}{ }_{ \pm 0.10}$ & $0.72^{\mathrm{ab}}{ }_{ \pm 0.20}$ \\
\hline & 0.8 & $1.56^{\mathrm{b}}{ }_{ \pm 0.57}$ & $0.32^{\mathrm{bc}}{ }_{ \pm 0.04}$ & $0.46^{\mathrm{b}}{ }_{ \pm 0.16}$ & $0.15^{\mathrm{bc}}{ }_{ \pm 0.09}$ & $0.69^{\mathrm{ab}}{ }_{ \pm 0.19}$ \\
\hline & 1.0 & $1.61^{\mathrm{b}}{ }_{ \pm 0.62}$ & $0.24^{\mathrm{c}}{ }_{ \pm 0.03}$ & $0.33^{\mathrm{a}}{ }_{ \pm 0.01}$ & $0.11^{\mathrm{a}}{ }_{ \pm 0.07}$ & $0.72^{\mathrm{ab}}{ }_{ \pm 0.80}$ \\
\hline & 2.0 & $0.67^{\mathrm{a}}{ }_{ \pm 0.32}$ & $0.16_{ \pm 0.03}^{\mathrm{a}}$ & $0.22^{\mathrm{a}}{ }_{ \pm 0.02}$ & $0.08^{\mathrm{b}}{ }_{ \pm 0.02}$ & $0.73^{\mathrm{ab}}{ }_{ \pm 0.29}$ \\
\hline
\end{tabular}

-Means with the same letter are not significantly different. ${ }^{-\#}$ Measured as $\left(\mu \mathrm{g} \mathrm{ml}^{-1}\right.$ algal suspension)

Thus, disturbances in the photosynthetic pigment contents of $C$. vulgaris accompanied with growth reduction would confirm the great correlation between photosynthesis and growth as recommended by our conclusions in C. salina. Thus, machinery of photosynthetic apparatus and its characteristics could drive growth (Shaddad et al., 2006 and Talebi et al., 2013).

Response of metabolite production to salt stress

Salinity stress induced a marked decrease in soluble sugars in $C$. vulgaris, where the highest decrease was $36 \%$ of the control at $0.8 \mathrm{M} \mathrm{NaCl}$. The total sugars remained more or less unchanged with salinity treatment (Fig.1). Interestingly, the reverse was true in $C$. salina, in which there was a considerable and irregular accumulation in soluble sugars. The highest accumulation was recorded 2.1-fold as compared to the control value at 1 molar $\mathrm{NaCl}$. The total saccharides increased irregularly in $C$. salina cultures, compared to the control (Fig.1).

In this work, the greater accumulation of soluble sugars in halophytic alga, as a response to salinity, seemed to represent an osmotic solute used for osmoregulation. So the highest increase in this fraction was accompanied with maximum increase in growth criteria (Rao et al., 2007). The reduction of sugars in $C$. vulgaris under stressed conditions was mostly associated with decreases in chlorophyll (Table1), which gave reason to predict that low chlorophyll content would cause a relevant reduction of light absorption (Tammam et al., 2011) and consequently reduces the biosynthesis of carbohydrates. Thus, the behaviors of the two algae under study differed greatly in the pattern of change of carbohydrates and their fractions, where they mostly conferred opposite to each other. 
Soluble protein content increased markedly in C.vulgaris as a result of salinity treatment and the highest increase was $21 \%$ over the control at 0.8 molar $\mathrm{NaCl}$, whereas total protein was significantly dropped (Fig.1). On the other hand, $C$. salina regulated its soluble protein content mainly around the control, especially up to $1 \mathrm{M} \mathrm{NaCl}$ then it decreased by $40 \%$. The total proteins showed a gradual slight increase up to $1 \mathrm{M} \mathrm{NaCl}$, after that, a slight decrease was shown (only 10\%) (Fig.1).
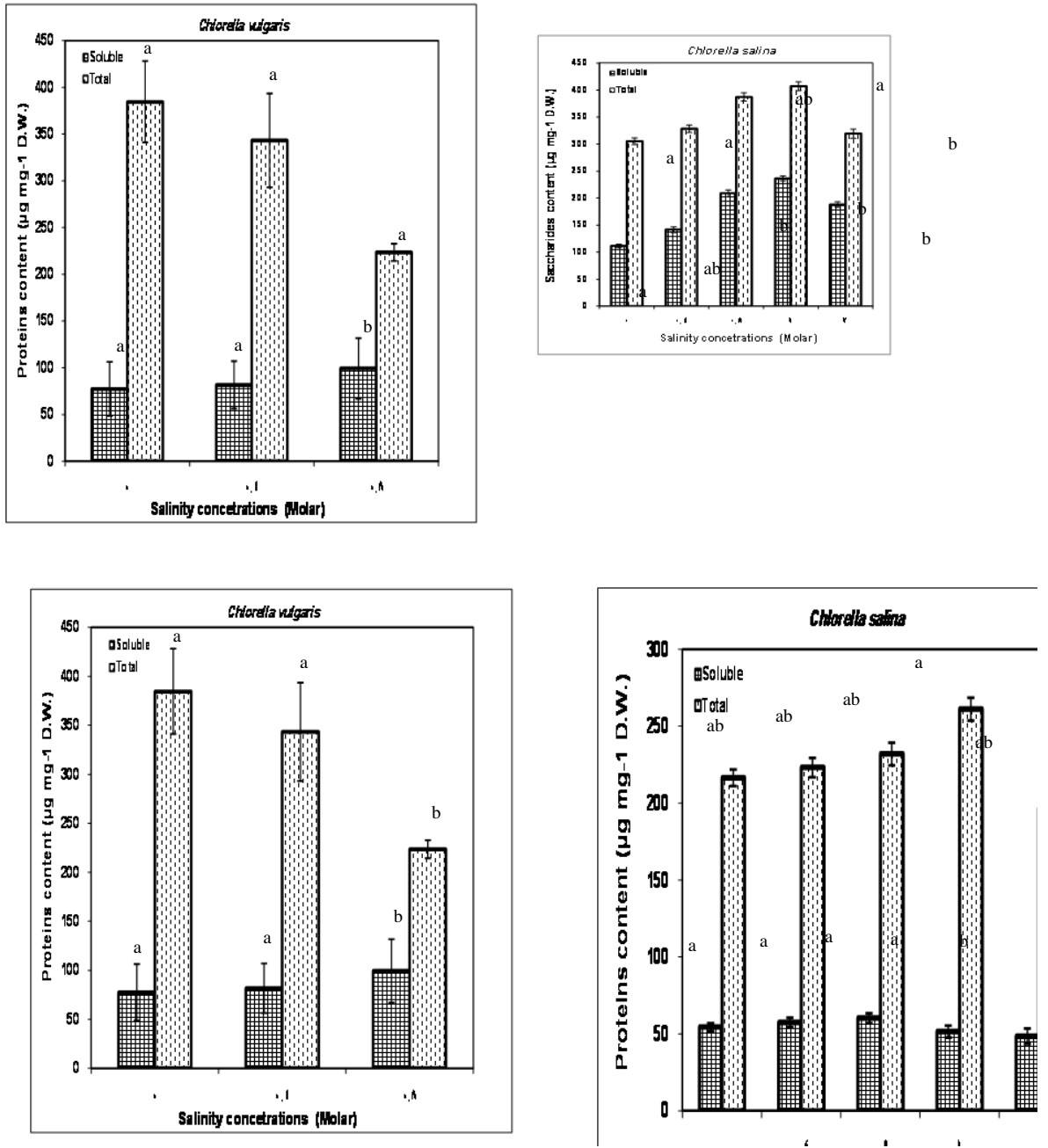

Fig. 1. Response of saccharide and protein contents $\left(\mu \mathrm{g} \mathrm{g}{ }^{-1}\right.$ D.W.) of $C$. vulgaris and $C$. salina to salt stress. The vertical bars represent standard deviation. Different letters above the bars indicate significant levels at $\mathbf{p}<0.05$. 
The results obtained might assume that

In $C$. vulgaris, the incorporation of carbohydrate into nitrogen was retarded since the recorded decrease in the carbohydrate pool was not met with enhanced levels of total protein. Consequently, the organism might achieve defense against salinity by increasing soluble proteins rather than soluble carbohydrates.

In $C$. salina, both soluble and total carbohydrate contents were enhanced with the increase of salinity. This was met with a concomitant increase of both soluble and total proteins, which might result from enhanced photosynthetic rates. Thus, in this algal species, the defense strategy against salinity seemed to take place through increased soluble carbohydrate concentration rather than soluble protein.

Salt stress induced an accumulation in free amino acids and proline contents with increasing salinity in C.vulgaris as compared to the control. The percent increase was 21.74 and $64.5 \%$ over the control, respectively at $0.8 \mathrm{M} \mathrm{NaCl}$, this corresponded to more than $70 \%$ reduction in growth. There was an irregular decrease in the total free amino acids and proline contents in C. salina (Table 2). In this investigation, the data of proline content revealed a negative correlation between growth criteria and proline accumulation in the two experimental algae (Galal and Farghl, 2006).

Tuna et al. (2008a) revealed that proline accumulation in salt stressed cells occurred by decreased proline oxidation to glutamic acid, decreased utilization for proline in proteins synthesis and enhanced proteins turnover.

TABLE 2. Comparison between total free amino acids (Total F.A.A), proline ,sodium $\left(\mathrm{Na}^{+}\right)$,potassium $\left(\mathrm{K}^{+}\right)$contents, $\mathrm{K}^{+} / \mathrm{Na}^{+}$ratio and malondialdehyde (MDA) content of $C$. vulgaris and $C$. salina grown under salt stress. Each value is a mean of replications \pm SD standard deviation.

\begin{tabular}{|c|c|c|c|c|c|c|c|}
\hline Strains & $\begin{array}{l}\text { Salinity } \\
\text { (M) }\end{array}$ & $\begin{array}{c}\text { Total } \\
\text { F.A.A } A^{\#}\end{array}$ & proline $^{\#}$ & $\mathrm{Na}^{+\#}$ & $\mathbf{K}^{+\#}$ & $\mathrm{~K}^{+} / \mathrm{Na}^{+}$ & MDA $^{*}$ \\
\hline \multirow{3}{*}{ C.vulgaris } & 0 & $12.06_{ \pm 2.58}^{\mathrm{a}}$ & $1.97^{\mathrm{a}} \pm 0.93$ & $5.40^{\mathrm{a}}{ }_{ \pm 0.10}$ & $28.00_{ \pm 0.06}^{\mathrm{a}}$ & $5.18_{ \pm 30}^{\mathrm{a}}$ & $55.78_{ \pm 23.23}^{\mathrm{a}}$ \\
\hline & 0.4 & $12.75^{\mathrm{a}} \pm 3.48$ & $2.32 \mathrm{a}^{\mathrm{b}}{ }_{ \pm 0.46}$ & $9.60^{\mathrm{b}}{ }_{ \pm 0.05}$ & $17.00_{ \pm 0.01}^{\mathrm{b}}$ & $1.77_{ \pm 0.20}^{\mathrm{b}}$ & $69.33^{\mathrm{ab}} \pm 47.25$ \\
\hline & 0.8 & $14.65^{\mathrm{ab}} \pm 3.62$ & $325^{\mathrm{b}} \pm 2.18$ & $23.32^{\mathrm{bc}}{ }_{ \pm 0.13}$ & $13.03^{\mathrm{b}}{ }_{ \pm 0.03}$ & $0.56_{ \pm 0.10}^{\mathrm{b}}$ & $90.0 \pm 48.39$ \\
\hline \multirow{5}{*}{ C.salina } & $\overline{0}$ & $21.81_{ \pm 0.10}^{\mathrm{a}}$ & $11.51^{\mathrm{a}}{ }_{ \pm 3.70}$ & $17.60^{\mathrm{a}}{ }_{ \pm 0.20}$ & $14.60^{\mathrm{ab}}{ }_{ \pm 0.30}$ & $0.83^{\mathrm{ab}}{ }_{ \pm 0.09}$ & $63.56^{\mathrm{a}} \pm 28.08$ \\
\hline & 0.4 & $18.89^{\mathrm{a}} \pm 0.05$ & $10.02^{\mathrm{a}}{ }_{ \pm 1.55}$ & $31.32^{\mathrm{b}}{ }_{ \pm 0.60}$ & $17.72^{\mathrm{ab}}{ }_{ \pm 0.40}$ & $0.55_{ \pm 0.03}^{\mathrm{c}}$ & $51.56^{\mathrm{ab}} \pm 27.03$ \\
\hline & 0.8 & $18.13^{\mathrm{ab}}{ }_{ \pm 0.09}$ & $9.69 \mathrm{a}^{\mathrm{b}}{ }_{ \pm 1.15}$ & $36.80_{ \pm 0.30}^{\mathrm{b}}$ & $17.53 \mathrm{a}_{ \pm 0.16}^{\mathrm{b}}$ & $0.48_{ \pm 0.06}^{\mathrm{c}}$ & $47.89 \pm 40.09$ \\
\hline & 1.0 & $16.77_{ \pm 0.15}^{\mathrm{b}}$ & $8.50^{b}{ }_{ \pm 1.63}$ & $40.80_{ \pm 0.30}^{b}$ & $18.93_{ \pm 0.50}^{\mathrm{a}}$ & $0.46_{ \pm 0.05}^{\mathrm{c}}$ & $62.56 \pm 59.95$ \\
\hline & 2.0 & $19.99^{\mathrm{a}}{ }_{ \pm 0.03}$ & $9.21^{\mathrm{ab}} \pm 2.10$ & $53.62^{\mathrm{b}}{ }_{ \pm 0.40}$ & $14.33^{\mathrm{ab}}{ }_{ \pm 0.40}$ & $0.27_{ \pm 0.02}^{\mathrm{c}}$ & $74.44^{\mathrm{ab}} \pm 39.82$ \\
\hline
\end{tabular}

- Means with the same letter are not significantly. \# Measured as $\left(\mu \mathrm{g} \mathrm{mg} \mathrm{m}^{-1}\right.$ dry weight). * Measured as (nmol g ${ }^{-1}$ fresh weight). 
From these results, it can be seen that, the differences in the accumulation of $\mathrm{Na}^{+}$in the two algae might be associated with the differences in the salt tolerance mechanisms of both algal cultures (Tuna et al., 2008a) and the $\mathrm{Na}^{+}$content and proline accumulation negatively correlated in $C$. salina. On the other hand, there was a positive correlation in the accumulation of $\mathrm{Na}^{+}$and proline in $C$. vulgaris where both increased progressively. The function of this osmoprotectant is presumed to be protective, with a role in scavenging free radicals and might be protected the dehydration of the cytoplasm as a result of the accumulation of $\mathrm{Na}^{+}$ (Mansour, 2000).

The $\mathrm{NaCl}$ salinity induced a highly significantly decreased in $\mathrm{K}^{+}$content in C.vulgaris by $53 \%$ at $0.8 \mathrm{M} \mathrm{NaCl}$, it on the other hand increased markedly in C.salina, then remained around control value (Tuna et al., 2008b). The concentration of $\mathrm{K}^{+} / \mathrm{Na}^{+}$ratio was significantly decreased in $C$. vulgaris and C. salina with salinity treatment. A high concentration of $\mathrm{Na}^{+}$can interfere with $\mathrm{K}^{+}$uptake, resulting in deficiency and stunted growth, and it has been suggested that in Vicia faba the two ions compete for uptake at the plasma membrane level (Ullah et al., 1993).

\section{Response of lipid peroxidation to salt stress}

Lipid peroxidation as an oxidative stress parameter showed a marked and progressive increase with elevation of salinity in C. vulgaris reaching about $61 \%$ over the control value at $0.8 \mathrm{M} \mathrm{NaCl}$. In $C$. salina, the amount of MDA content decreased up to $1 \mathrm{M} \mathrm{NaCl}$ and increased marginally by about $17 \%$ at $2 \mathrm{M} \mathrm{NaCl}$ (Table 2).

The increase in the products of lipid peroxidation might suggest a reduced ability of the test organisms to scavenge free radicals efficiently (Chris et al., 2006) and an increased permeability of plasma membrane or less membrane integrity (Chai et al., 2005). These could be correlated with the accumulation of ions and reactive oxygen species (ROS) production under salt stress (Sairam and Srivastava, 2002).

These conclusions might interpret the recorded correlation between the magnitude of growth inhibition in $C$. vulgaris and the enhancement levels of lipid peroxidation (Koca et al., 2007).

Response of some antioxidant enzymes activity to salt stress

The data in Fig. 2 reveal that the activity of superoxide dismutase (SOD) was gradually increased with salinity stress in C. vulgaris culture reaching about $34 \%$ over the control at $0.8 \mathrm{M} \mathrm{NaCl}$, while in $C$. salina salt stress induced consistent changes in the activity of this enzyme.

Catalase (CAT) activity increased markedly with salinity stress in $C$. vulgaris. The activity of CAT was about 3 - folds of the corresponding control at high level of $\mathrm{NaCl}$. In contrast, $C$. salina showed insignificant changes in the activity of CAT enzyme with minor reductions at 0.8 and $1.0 \mathrm{M} \mathrm{NaCl}$.

Egypt. J. Bot., 55, No. 1 (2015) 
Hypo and hyper saline media induced significant decrease in the activity of peroxidase (POD) of $C$. salina up to 1 molar $\mathrm{NaCl}$ then increase by $27 \%$ over the control was obtained. On the other hand, there was a gradual increase in POD activity of $C$. vulgaris culture reaching about $40 \%$ of the control at 0.8 molar $\mathrm{NaCl}$.
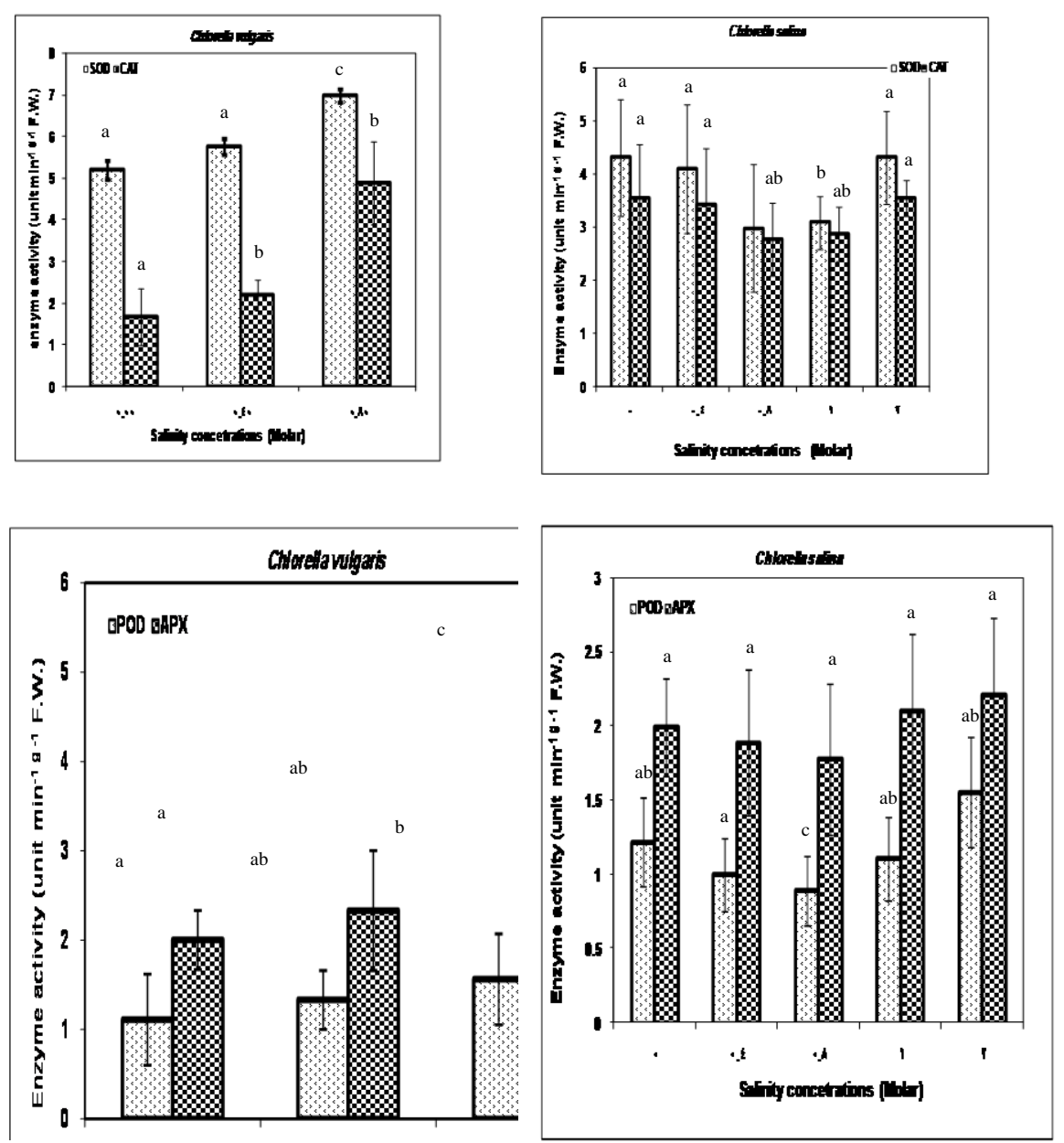

Fig. 2. Response of the activities of antioxidant enzymes (unit $\min ^{-1} \mathrm{~g}^{-1} \mathrm{~F}$.W.) in $C$. vulgaris and $C$. salina to salt stress. The vertical bars represent the standard deviations. Different letters above the bars indicate significant levels at $\mathbf{p}$ $<\mathbf{0 . 0 5}$. 
Ascorbate peroxidase (APX) activity was highly significantly increased with increasing salinity stress in $C$. vulgaris culture, where it was 2.1 fold of the control at $0.8 \mathrm{M} \mathrm{NaCl}$. In $C$. salina the changes in APX activity in both hypo and hyper saline media were generally non significant.

Antioxidant enzymes are known to play important roles in the defense mechanisms against stress and may provide a strategy to enhance salt tolerance in plants (Jaleel et al., 2007b and Abd El Baky et al., 2014). The mechanism by which salinity affects the antioxidant responses is not yet clear. It might be either due to (i) an effect of $\mathrm{Cl}^{-}$toxicity on Photosystem II or (ii) change in membrane integrity caused by a high $\mathrm{Na}^{+}$to $\mathrm{Ca}^{2+}$ ratio (Meneguzzo et al., 1999).

The decrease in SOD activity could impair the $\mathrm{O}_{2}{ }^{-}$scavenging system of cells and favor accumulation of $\mathrm{O}_{2}^{-}$and $\mathrm{H}_{2} \mathrm{O}_{2}$ which could lower the SOD activity (Jaleel et al., 2008).

Stimulation of CAT activity might result in protection from oxidative damage by rapid removal of $\mathrm{H}_{2} \mathrm{O}_{2}$ (Portune et al., 2010). Such reduction in CAT activity would result in $\mathrm{H}_{2} \mathrm{O}_{2}$ accumulation, which might react with $\mathrm{O}_{2}^{-}$to produce hydroxyl-free radical via Hebert-Weiss reaction (Xie et al., 2008).

POD activity may increase due to enhancement of the enzyme encoding genes or to a fine control-activation of already existing enzymes as suggested by (Dionsiso-Sese and Tobita, 1998).

Stimulation of APX activity in C. vulgaris under salinity stress might be due to the fact that, APX is involved in the degradation of $\mathrm{H}_{2} \mathrm{O}_{2}$ generated under salinity condition. A similar result has been observed in the green micro alga D. tertiolecta in response to high salt stress where APX activity increased as defensive responses to remove ROS and keep cellular ascorbic acid level constant (Jahnke and White, 2003). Considerable evidence shows that high peroxidase activity is correlated with the reduction of algal growth (Zheng and Van Huystee, 1992).

\section{Conclusion}

The green alga Chlorella can adapt to saline environments and it is considered a model organism for salinity tolerance. The great differences in the responses of the marine alga ( $C$. salina) and that of fresh water alga ( $C$. vulgaris) to the effect of $\mathrm{NaCl}$ salinity might reflect differences in their gene expression. Fresh water alga (C. vulgaris) increased activities of protective enzymes to detoxify and eliminate, the highly ROS levels under salinity stress is a good strategy for defensive mechanism. This study strongly suggests that induction of antioxidants is one component of the tolerance mechanism of Chlorella species to salinity as evidenced by growth behavior.

Egypt. J. Bot., 55, No. 1 (2015) 


\section{References}

Abd El Baky, H.H., Hussein M.M. and El-Baroty, G.S. (2014) Induces of antioxidant compounds and salt tolerance in wheat plant, irrigated with seawater as response to application of microalgae spray. Am. J Agr \& Biol Sci., 9 (2): 127-137

Alkayal F, Albion R.L., Tillett R.L., Hathwaik L.T., Lemos, M.S. and Cushman J.C. (2011) Expressed sequencetag (EST) profiling in hyper saline shocked Dunaliella salina reveals high expression of protein synthetic apparatus components. Plant Sci., 179:437-449.

Annan, J. N. (2014) Growth and photosynthesis response of the green alga, Picochlorum oklahomensis to iron limitation and salinity stress. Int. J. Plant Physiol. Biochem., 6(1): 7-18

Asada, K. and Chen, G. (1992) On activation of ascorbate peroxidase by thiols requires hydrogen peroxide. Plant Cell Physiol., 33: 117-123.

Ashraf M., and Harris, P.J.C. (2004) Potential biochemical indicators of salinity tolerance in plants. Plant Sci., 166:3-16.

Azevedo Neto, A.D., Prisco, J.T., Enéas-Fihlo, J., Abreu, C.E.B. and Gomes-Fihlo, E. (2006) Effect of salt stress on antioxidative enzymes and lipid peroxidation in leaves and roots of salt-tolerant and salt-sensitive maize genotypes. J. Environ. Exp. Bot., 56(1): 87-94.

Badour, S.S.A. (1959) Analytisch-chemische untersuchung des kaliummangles bei Chlorella im Vergleich mit anderen Mangelezustanden Ph.D. Dissertation Göttingen., 1: 199 .

Bates, L.S., Waldren, R.P. and Tear, L.D. (1973) Rapid determination of free proline for water-stress studies. Plant Soil., 39: 205-207.

Ben-Amtoz, A. Tornabene, T. and Thomas, W.H. (1985) Chemical profile of selected species of microalgae with emphasis on lipids. J. Phycol., 21: 72-81.

Bischoff, H.W. and Bold, H.C. (1963) Phycological studies. 4-some soil algae from enchanted rock and related algal species. Univ., Texas. Publ., 631: 32-38.

Chai, T., Fadzillah, M., Kusnan, M. and Mahmood, M. (2005) Water stress-induced oxidative damage and antioxidant responses in micropropagated banana plantlets. Biol Planta, 49(1):153-156.

Chris, A., Zeeshan, M. and Abraham, G. (2006) Algae. Environ. Exp. Bot., 57: 154-159.

Dhindsa, R.S. and Matowe, W. (1981) Drought tolerance in two mosses: correlated with enzymatic defense against lipid peroxidation. J. Exp. Bot., 32: 79-91. 
Dionsiso-Sese, M.L. and Tobita, S. (1998) Antioxidant responses of rice seedlings to salinity stress. Plant Sci., 135: 1-9.

EL-Sheekh M.M. and Omar, H.H. (2002) Effect of high salt stress on growth and fatty acids content of the unicellular green alga Chlorella vulgaris. Az. J. Microbiol., 55: 181-191.

Fathi, M. and Asem, A. (2013) Investigating the impact of $\mathrm{NaCl}$ salinity on growth, $\beta$ carotene, and chlorophyll $a$ in the content life of halophytes of algae Chlorella sp. AACL Bioflux, 6(3): 241-245.

Fuchen, S. and Fang, B. (2007) Effects of salinity and temperature stress on ecophysiological characteristics of exotic cordgrass, Spartina alterniflora. Acta Ecol. Sinica., 27(7): 2733-2741.

Galal, H.R.M. and Farghl, A.A.M. (2006) The changes in growth , carbohydrates, proline, amino acids and protein contents of salinized Chlorella elliposidea. Assiut. Univ. J. Bot., 35: 129-149.

Grumet, R., Isleib, T.G. and Hanson, A.D.(1985) Genetic control of glycinebetaine level in barley. Crop Sci., 25: 618-622.

Guillard R., and Ryther J. (1963) Studies on marine planktonic diatoms. I. Cyclotella nana Husted and Detonula confervacea Cleve. Can. J. Microbiol. 8: 229- 239.

Havir, E.A. and Mellate, N.A. (1987) Biochemical and developmental characterization of multiple forms of catalase in tobacco leaves. Plant Physiol, 84: 450-455.

Heath, R.L. and Packer, L. (1968) Photoperoxidation in isolated chloroplasts: I. Kinetics and stiochiometry of fatty acid peroxidation. Arch. Bioch. Biophys, 125: 189-198.

Hiremath S. and Mathad P. (2010) Impact of salinity on the physiological and biochemical traits of Chlorella vulgaris Beijerinck. J. Algal Biomass Utln., 1(2): 51-59

Jahnke, L.S. and White, A. (2003) Long-term hyposaline and hypersaline stresses produce distinct antioxidant responses in the marine alga Dunaliella tertiolecta. $J$ Plant Physiol. 160:1193-1202

Jaleel, C.A., Gopi, R., Sankar, B., Gomathinayagam, M. and Panneerselvam, R. (2008) Differential responses in water use efficiency in two varieties of Catharanthus roseus under drought stress. C. R. Biolog. 331(1): 42-47.

Jaleel, C.A., Manivannan, P., Lakshmanan, G.M.A., Sridharan, R. and Panneerselvam, R. (2007b) $\mathrm{NaCl}$ as a physiological modulator of proline metabolism and antioxidant potential in Phyllanthus amarus. C. R. Biolog. 330: 806-813.

Jaleel, C.A., Manivannan, P., Sankar, B., Kishorekumar, A. and Panneerselvam, R. (2007a) Calcium chloride effects on salinity-induced oxidative stress, proline metabolism and indole alkaloid accumulation in Catharanthus roseus. C. R. Biolog. 330: $674-683$.

Egypt. J. Bot., 55, No. 1 (2015) 
Klapheck, S., Zimmer, I. and Cosse, H. (1990) Scavenging of hydrogen peroxide in endosperm of Ricinus communis by ascorbate peroxidase. Plant Cell Physiol. 31: 1005-1013.

Koca, H., Bor, M., Özdemir, F. and Türkan, I. (2007) The effect of salt stress on lipid peroxidation, antioxidative enzymes and proline content of sesame cultivars. Environ. Exp. Bot., 60: 344-351.

Kreslavski, V.D., Carpentier, R., Klimov, V.V., Murata, N. and Allakhverdiev, S.I. (2007) Molecular mechanisms of stress resistance of the photosynthetic apparatus. Biochemistry (Moscow) Supplement Series A: Membrane and Cell Biology, 1: 185-205.

Leganes, F., Sanchez-Maeso, E. and Fernandez-Valiente, E. (1987) Effect of indole acetic acid on growth and dinitrogen fixation by blue-green algae. Sven. Bot. Tidskr., 64: $460-461$.

Leshem, Y., Seri, L. and Levine, A. (2007) Induction of phosphatidylinositol 3 kinasemediated endocytosis by salt stress leads to intracellular production of reactive oxygen species and salt tolerance. The Plant J., 51: 185-197.

Lorenzen, H. (1964) "Synchronization of Chlorella With Light Dark Changes and Periodical Dilution to a Standard Cell Number". In: Zeiten, E. (Ed.), Inersci. Publ., New York. pp.571.

Lowery, O.H., Rasebrough, N.J., Farr, A.L. and Randall, R. J. (1951) Protein measurement with the Folin phenol reagent. J. Biol. Chem., 193: 291-297.

Mansour, M.M.F. (2000) Nitrogen containing compounds and adaptation of plants to salinity stress. Biol. Plant., 43: 491-500.

Marnett, L. (2000) Oxyradicals and DNA damage. Carcinogenesis, 21(3): 361-370.

Meneguzzo, S., Navari-Izzo, F. and Izzo, R. (1999) Antioxidative responses of shoots and roots of wheat to increasing $\mathrm{NaCl}$ concentrations, J. Plant Physiol., 155: 274-280.

Metzner, H., Rau, H. and Senger, H. (1965) To synchronsiser bakeit investigations of individual pigment-deficiency mutants of Chlorella. Planta., 65: 186-194.

Mgbeze G.C., and Omodamwen, J.O. (2011) Nutrient uptake in pepper (Capsicum annuum L.) grown under salt stress. J. Agric. Bio. Sci., 2(4):99-107.

Moore, S. and Stein, W.W. (1948) Amino acid free photometric ninhydrin method for use in the chromatography of amino acids. J. Biol. Chem., 176: 367-388.

Mukherjee, S.P. and Choudhuri, M.A. (1983) Implications of water stress-induced changes in the levels of endogenous ascorbic acid and hydrogen peroxide in Vigna seedlings. Plant Physiol., 58: 166-170. 
Portune, K.J., Cary, S.C. and Wamer, E.W. (2010) Antioxidant enzyme response and reactive oxygen species production in marine raphidophytes $J$. of Phycology, 46: 1161-1171

Rao, A.R., Dayananda C., Sarada R., Shamala T.R. and Ravishankar G.A. (2007) Effect of salinity on growth of green alga Botryococcus braunii and its constituents. Biores.Technol., 98: 560-564.

Sairam, R.K. and Srivastava. G.C. (2002) Changes in antioxidant activity in sub-cellular fractions of tolerant and susceptible wheat genotypes in response to long term salt stress. Plant Sci., 162: 897-904.

Sekmen, A.H., Türkan İ. and Takio S. (2007) Differential responses of antioxidative enzymes and lipid peroxidation to salt stress in salt tolerant Plantago maritima and salt-sensitive Plantago media. Physiol. Plant, 131: 399-411

Shaddad, M.A.K., Abd El-samad, H.M. and Mostafa, D. (2006) Interaction effect of salinity and GA3 on growth, $\mathrm{K}+/ \mathrm{Na}+$ ratio. antioxidant enzymes and lipid peroxidation in two wheat cultivars. Assiut Univ. J. Bot., 35: 251-260.

Talebi, A.F., Tabatabaei, M., Mohtashami, S.K., Tohidfar, M. and Moradi, F. (2013) Comparative salt stress study on intracellular ion concentration in marine and saltadapted freshwater strains of microalgae. Not. Sci. Biol., 5(3):309-315

Tammam, A.A., Fakhry, E.M. and El-Sheekh, M. (2011) Effect of salt stress on antioxidant system and the metabolism of the reactive oxygen species in Dunaliella salina and Dunaliella tertiolecta. Afr. J. Biotechnol., 10(19): 3795-3808

Teixeira, J. and Pereira, S. (2007) High salinity and drought act on an organ-dependent manner on potato glutamine synthetase expression and accumulation. Environ. Exp. Bot., 60:121-126.

Tuna, A.L., Kaya, C., Higgs, D., Murillo-Amador, B., Aydemir, S. and Girgin, A.R. (2008a) Silicon improves salinity tolerance in wheat plants. Environ. Exp. Bot., 62: 10-16.

Tuna, A.L., Kayab, C., Dikilitas, M. and Higgs, D. (2008b) The combined effects of gibberellic acid and salinity on some antioxidant enzyme activities, plant growth parameters and nutritional status in maize plants. Environ. Exp. Bot., 62: 1-9.

Turhan, E., Gulen, H. and Er, A. (2008) The activity of antioxidative enzymes in three strawberry cultivars related to salt-stress tolerance. Acta Physiol. Plant., 30: 201-208.

Ullah, S.M., Soja, G. and Gerzabek, M.H. (1993) Ion uptake, osmoregulation and plant water relationsin faba beans (Vicia faba L.) under salt stress. Die Bodenkultur, 44: 291-303.

Xie, Z., Duan, L., Tain, X., Wang, B., Eneji, E. and Li, Z. (2008) Coronatine alleviates salinity stress in cotton by improving the antioxidant defense system and radical scavenging activity. Plant Physiol., 165: 375-384.

Zheng, X. and Van Huystee, R.B. (1992) Peroxidase-regulated elongation of segments from Peanut hypocotyls. Plant Sci., 81: 47-56.

(Received $2 / 4 / 2014$ accepted $27 / 10 / 2014$ )

Egypt. J. Bot., 55, No. 1 (2015) 
EFFECT OF SALT STRESS ON GROWTH, ANTIOXIDANT ENZYMES ... 15

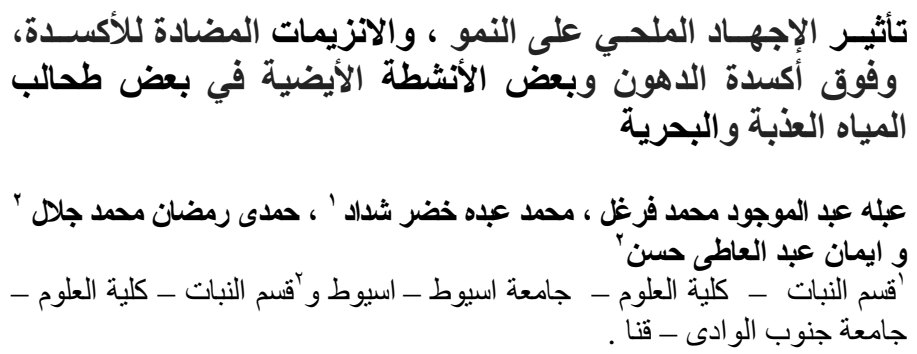

يهدف هذا البحث إلى مقارنة الاستجابة الفسيولوجية لطحالب المياه العذبة (كلوريلا

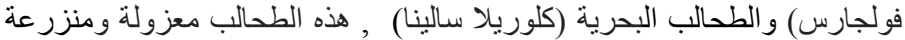

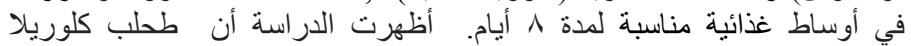

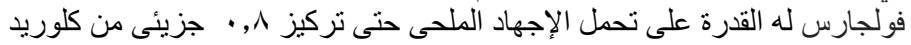

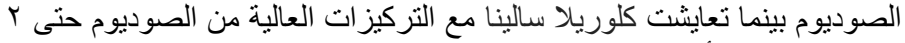

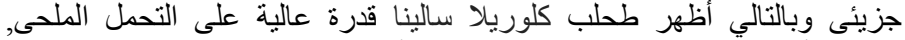
فى حين أظهر طُلب كلب كلوريلا فولجارس قدرة أ قل على على التحمل الملحى.

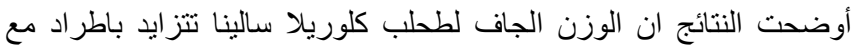

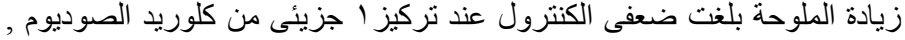

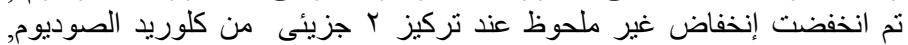
في حين لوحظ انخفاض شديد فى الوزن الجاف لطحلب كلوريلا فولجن لجارس.

وقد أدت التركيزات المنخفضة والمرتفعة من كلوريد الصوديوم الى زيادة الصناة

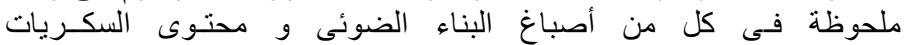

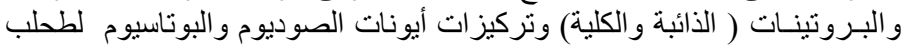

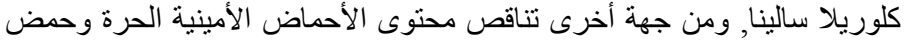

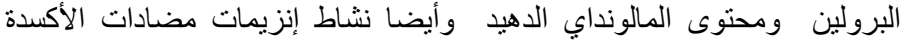

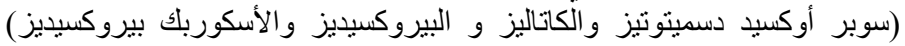

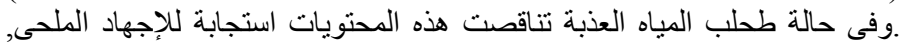

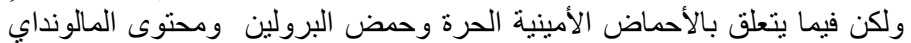

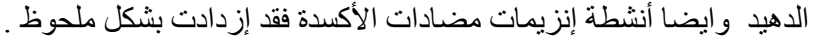

بناء على النتائج السابقة فقد يتضح أن المقاومة الكبيرة لطحلب كلوريلا سالينا

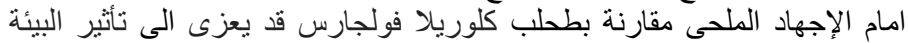

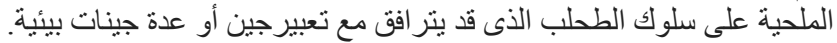

10 